\title{
Rancang Bangun Sistem Informasi Pengelolaan Berkas Pada Kantor Notaris/PPAT I Gusti Rai Daniel Ari Putra, SH., M.KN.
}

\author{
Welda*, Desak Made Dwi Utami Putra**, Ayu Manik Dirgayusari*** \\ * Teknik Informatika, STMIK STIKOM Indonesia \\ ** Teknik Informatika, STMIK STIKOM Indonesia \\ *** Sistem Komputer, STMIK STIKOM Indonesia \\ *welda@stiki-indonesia.ac.id, **desak.utami@stiki-indonesia.ac.id,***ayu.manik@stiki-indonesia.ac.id
}

\begin{abstract}
Notary Office / PPAT I Gusti Rai Daniel Ari Putra, SH., M.Kn. is a Land Deed Making Official who makes deeds related to land. In carrying out this work, records are still carried out manually, namely still using a recording system in the book which consists of a file monitoring management process, payment for services, and does not provide information regarding the reporting of files that have been completed. This results in each service requiring time from the time the application is submitted to the completion of the file, besides that proof of payment for services can be lost if not recorded. Based on these problems, needed a system to facilitate the management of the file being executed and facilitate business processes that exist in this study created a system with the title Design of Information System File Management in the Office of Notary / PPAT which include data management of the applicant, the data in the file status request, payments and report. This research process uses a linear sequential model method, starting from determining needs, analyzing needs and designing CDM and PDM for the next steps. Furthermore, the authors build and design a system using the PHP programming language and MySQL as a database. The final result of this research is a file management information system at the Notary Office I Gusti Rai Daniel Ari Putra, SH., M.Kn. and testing has been carried out on the system using black box testing whose results are in accordance with the system design.
\end{abstract}

Keyword: Sistem Informasi, Pengelolaan Berkas, PPAT.

\begin{abstract}
ABSTRAK
Kantor Notaris/PPAT I Gusti Rai Daniel Ari Putra, SH., M.Kn. adalah Pejabat Pembuat Akta Tanah yang membuat akta otentik berhubungan dengan pertanahan. Dalam melakukan pekerjaan tersebut masih dilakukan pencatatan secara manual, yaitu masih menggunakan sistem pencatatan pada buku yang terdiri dari proses pengelolaan pemantauan berkas, pembayaran jasa, dan tidak menyediakan informasi mengenai pelaporan berkas yang telah selesai dikerjakan. Hal tersebut mengakibatkan setiap layanan jasa memerlukan waktu pada saat mulai pengajuan permohonan sampai dengan selesai berkas selain itu bukti pembayaran jasa bisa hilang jika tidak dicatatkan. Berdasarkan permasalahan tersebut, di butuhkan sistem untuk memudahkan dalam pengelolaan berkas yang sedang dijalankan dan memudahkan proses bisnis yang ada pada penelitian ini dibuatkan suatu sistem dengan judul Rancang Bangun Sistem Informasi Pengelolaan Berkas pada Kantor Notaris/PPAT yang mencangkup pengelolaan data pemohon, data status berkas permohonan, pembayaran dan laporan. Proses penelitian ini menggunakan metode linear sequential model, dimulai dari menetapkan kebutuhan, melakukan analisa kebutuhannya dan merancang CDM dan PDM untuk dilakukan langkah berikutnya. Selanjutnya, penulis membangun dan merancang sistem menggunakan bahasa pemograman PHP dan MySQL sebagai database. Adapun hasil akhir dari penelitian ini adalah sebuah sistem informasi pegelolaan berkas pada Kantor Notaris I Gusti Rai Daniel Ari Putra, SH., M.Kn. dan telah dilakukan pengujian pada sistem dengan menggunakan pengujian black box yang hasilnya telah sesuai dengan perancangan sistem.
\end{abstract}

Keyword: Sistem Informasi, Pengelolaan Berkas, PPAT.

\section{Introduction}

Notaris/Pejabat Pembuat Akta Tanah (selanjutnya disebut Notaris/PPAT) adalah pejabat yang di angkat oleh Pemerintah yang memperoleh kewenangan secara atributif dari Negara. Secara terpisah Notaris dan PPAT memiliki kewenangan yang berbeda. Jabatan Notaris atau disebut juga dengan UUJN, menyatakan bahwa Notaris merupakan jabatan tertentu yang menjalankan profesi dalam pelayanan hukum kepada masyarakat [1]. Adapula yang menyebutkan PPAT adalah pejabat umum yang di beri kewenangan untuk membuat akta-akta otentik mengenai perbuatan hukum tertentu mengenai hak atas tanah [2]. PPAT pada saat sekarang ini di 
berikan mandat oleh peraturan perundang-undangan yang ada untuk membuat akta otentik yang berhubungan dengan tanah. Ketentuan mengenai jabatan PPAT pada saat ini di atur dalam Peraturan Pemerintah Nomor 37 Tahun 1998 tentang Peraturan Jabatan Pejabat Pembuat Akta Tanah (PP Nomor 37 Tahun 1998). Di undangkannya PP Nomor 37 Tahun 1998 ini berdasarkan amanat dari Undang-Undang Nomor 5 Tahun 1960 tentang Undang-Undang Pokok Agraria atau disebut juga dengan UUPA yang telah mengamanatkan pemerintah untuk melaksanakan pendaftaran tanah. Amanat UUPA dalam melaksanakan pendaftaran tanah ini kemudian di implementasikan dengan di keluarkannya Peraturan Pemerintah Nomor 24 Tahun 1997 tentang Pendaftaran Tanah [3]. Seiring dengan perkembangan teknologi informasi yang semakin pesat kebutuhan akan data dan informasi sangat di perlukan dalam proses bisnis, hal tersebut juga di butuhkan pada perusahaan ataupun perseorangan. Salah satu perusahaan yang membutuhkannya yaitu bergerak dalam bidang jasa pembuatan akta dan pertanahan Kantor Notaris/PPAT agar menjadi lebih baik. Pada kantor Notaris/PPAT I Gusti Rai Daniel Ari Putra, SH., M.Kn. dalam menjalankan proses bisnisnya perusahaan tersebut masih melakukan pencatatan secara manual, yaitu masih menggunakan sistem pencatatan di buku besar yang terdiri dari proses pengelolaan pemantauan berkas, pembayaran jasa. Pada setiap layanan jasa memerlukan waktu untuk memprosesnya, sehingga dalam melanjutkan pencatatan pada buku besar memakan waktu yang lama dalam mencari data klien untuk mencatat kembali data yang terbaru dalam menjalankan berkas yang sedang di ajukan, untuk kwitansi pembayaran jasa bisa hilang atau terselip dengan kertas yang lainnya dan tidak adanya rekapan laporan berkas yang telah selesai di kerjakan. Perusahaan tersebut tidak menyediakan informasi mengenai pelaporan berkas yang telah selesai di kerjakan. Oleh karena itu di butuhkan sistem untuk memudahkan staff dalam pengelolaan berkas yang sedang di jalankan sehingga memudahkan proses bisnis yang ada pada kantor Notaris/PPAT tersebut. Sistem adalah rangkaian dari dua atau lebih komponenkomponen yang saling berhubungan, yang berinteraksi untuk mencapai suatu tujuan. Sebagian besar sistem terdiri dari subsistem yang lebih kecil yang mendukung sistem yang lebih besar [4]. Agar target dari system bisa tercapai, maka target atau sasaran tersebut harus di ketahui terlebih dahulu ciri-ciri atau kriterianya. Upaya mencapai sasaran tanpa mengetahui ciri-ciri atau kriteria dari sasaran tersebut kemungkinan besar sasaran tersebut tidak akan pernah tercapai [6]. Metode linier sequensial digunakan untuk menyelesaikan sistem informasi tersebut. Langkah-langkahnya dimulai dengan menetapkan kebutuhan oleh seluruh sistem, melakukan analisa terhadap kebutuhan sistem, melakukan perancangan dari hasil analisis, membuat kode dari hasil perancangan dan melakukan pengujian dari sistem yang sudah dibuat [5]. Dengan rancang bangun sistem informasi ini di harapkan dapat mempermudah pekerjaan dan meningkatkan ketelitian dalam bekerja.

\section{Research Method}

Metode yang digunakan untuk membangun sistem ini adalah linear sequential model. Proses yang dilakukan meliputi menetapkan kebutuhan oleh seluruh sistem, melakukan analisa terhadap kebutuhan sistem, melakukan perancangan dari hasil analisis, membuat kode dari hasil perancangan dan melakukan pengujian dari sistem yang sudah dibuat. Proses awal adalah melakukan pengumpulan data yang dibutuhkan untuk membangun sistem informasi ini yaitu dengan melakukan wawancara serta observasi secara langsung ke kantor notaris. Dengan hasil wawancara dan obesrvasi dapat dianalisis semua kebutuhan dari sistem yang akan dibuat, hasil analisis digunakan untuk melakukan perancangan dimulai dengan context diagram, DFD, CDM dan PDM. Langkah selanjutnya adalah menuangkan semua perancangan kedalam bentuk kode bahasa PHP dan MySQL sebagai database. Langkah terakhir adalah proses pengujian dari sistem yang telah dibuat.

\subsection{Metode Pengumpulan Data}

Wawancara dilakukan pada Kantor Notaris/PPAT I Gusti Rai Daniel Ari Putra, SH., M.Kn. yang beralamatkan di Jalan Kebo Iwa Selatan, untuk menggali informasi melalui berbicara langsung kepada narasumber. Berkonsultasi dengan pihak yang bersangkutan untuk mendapatkan data yang di butuhkan. Dari hasil wawancara yang dilakukan di dapat yaitu proses pengelolaan berkas yang sedang berjalan dalam pemantauan berkas masih menggunakan catatan untuk tahapannya, pembayaran yang masih menggunakan kertas kwitansi dan tidak adanya laporan pembayaran. Dilakukan observasi langsung untuk mendapatkan data mengenai proses pengerjakan berkas yang sedang di ajukan pada kantor Notaris/PPAT I Gusti Rai Daniel Ari Putra, SH., M.Kn. mulai dari pengajuan berkas hingga berkas telah selesai untuk pembayaran dan laporan pembayaran. Kepustakaan di ambil dari jurnal-jurnal yang dapat menunjang penelitian. Adapun jurnal yang di pergunakan dalam penelitian adalah jurnal yang membahas tentang website dan sirkulasi berkas. Dan dokumentasi yaitu dengan cara mempelajari alur pekerjaan yang di ajukan oleh pemohon, kemudian selanjutnya yang akan di proses dikantor pertanahan dan tahapan terakhir adalah membuat laporan pembayaran.

\subsection{Analisa Kebutuhan}

1. Yang pertama yaitu pemohon mengajukan permohonan dan memberikan semua kelengkapan berkas yang di butuhkan untuk peralihan hak sertifikat yang akan di proses. 
2. Staff mengecek kelengkapan berkas jika berkas tidak lengkap maka staff akan memberikan informasi kapada klien, jika kelengkapan permohonan semuanya telah di penuhi maka staff akan membuat draft akta dan kemudian bila akta sudah selesai di draft maka PPAT melakukan pembacaan akta.

3. Selanjutnya yaitu mulai menjalankan berkas di ajukan terlebih dahulu ke Badan Pendapatan Daerah lalu ke Kantor Pajak Pratama kemudian yang terakhir kepada kantor Pertanahan berdasarkan letak tanah itu berada. Dan staff mencatat setiap proses alur berjalannya berkas yang sedang di jalankan.

4. Setelah permohonan telah selesai maka staff menginformasikan pembayaran kepada klien kemudian klien melakukan pembayaran.

5. Staff menerima uang pembayaran atas jasa yang telah di gunakan oleh klien. Dan staff membuat kwitansi, kemudian staff menyerahkan berkas dan kwitansi kepada PPAT untuk di serahkan kepada klien.

6. Kemudian PPAT menyerahkan sertifikat kepada klien, dan kemudian klien menerima berkas yang telah selesai di kerjakan.

Dari hasil analisa didapatkan bahwa semua fungsi pada system akan dikerjakan oleh staff dari kantor notaris. Staff dapat melakukan penambahan dan memodifikasi data pemohon, mencatat keperluan berkas pemohon dan mencetak kwitansi pembayaran.

\section{Result and Analysis}

Diagram Context bertujuan untuk memetakan keseluruhan sistem terdapat 2 entitas yaitu staff dan Klien. Staff mengelola data Pemohon, data status permohonan, data pembayaran, laporan berkas yang telah selesai dikerjakan.

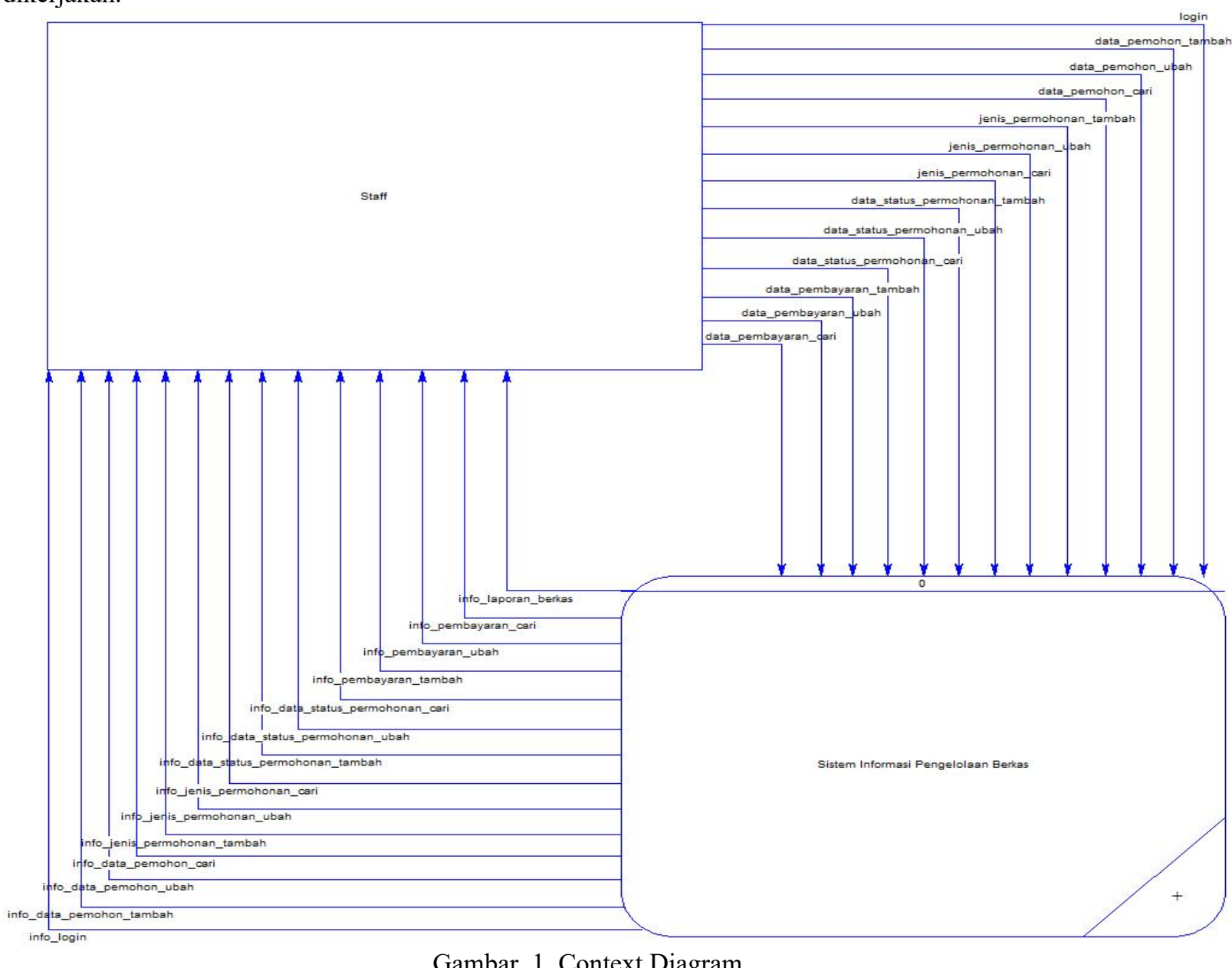

Gambar 1. Context Diagram 


\subsection{Conceptual Data Model (CDM)}

Conceptual Data Model dari sistem pengelolaan berkas.

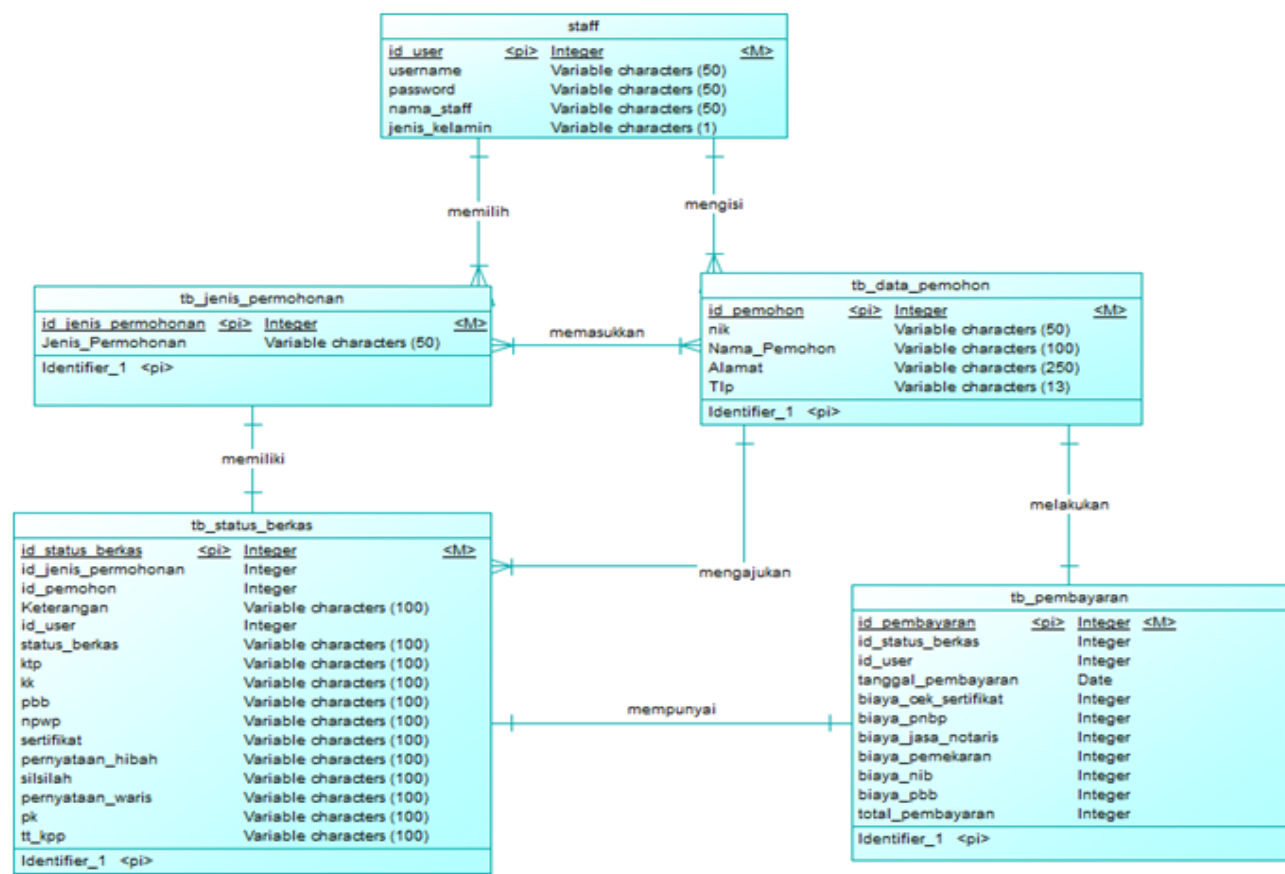

Gambar 2. Conceptual Data Model

3.2 Physical Data Model (PDM)

Phisycal Data Model dari sistem pengelolaan berkas.

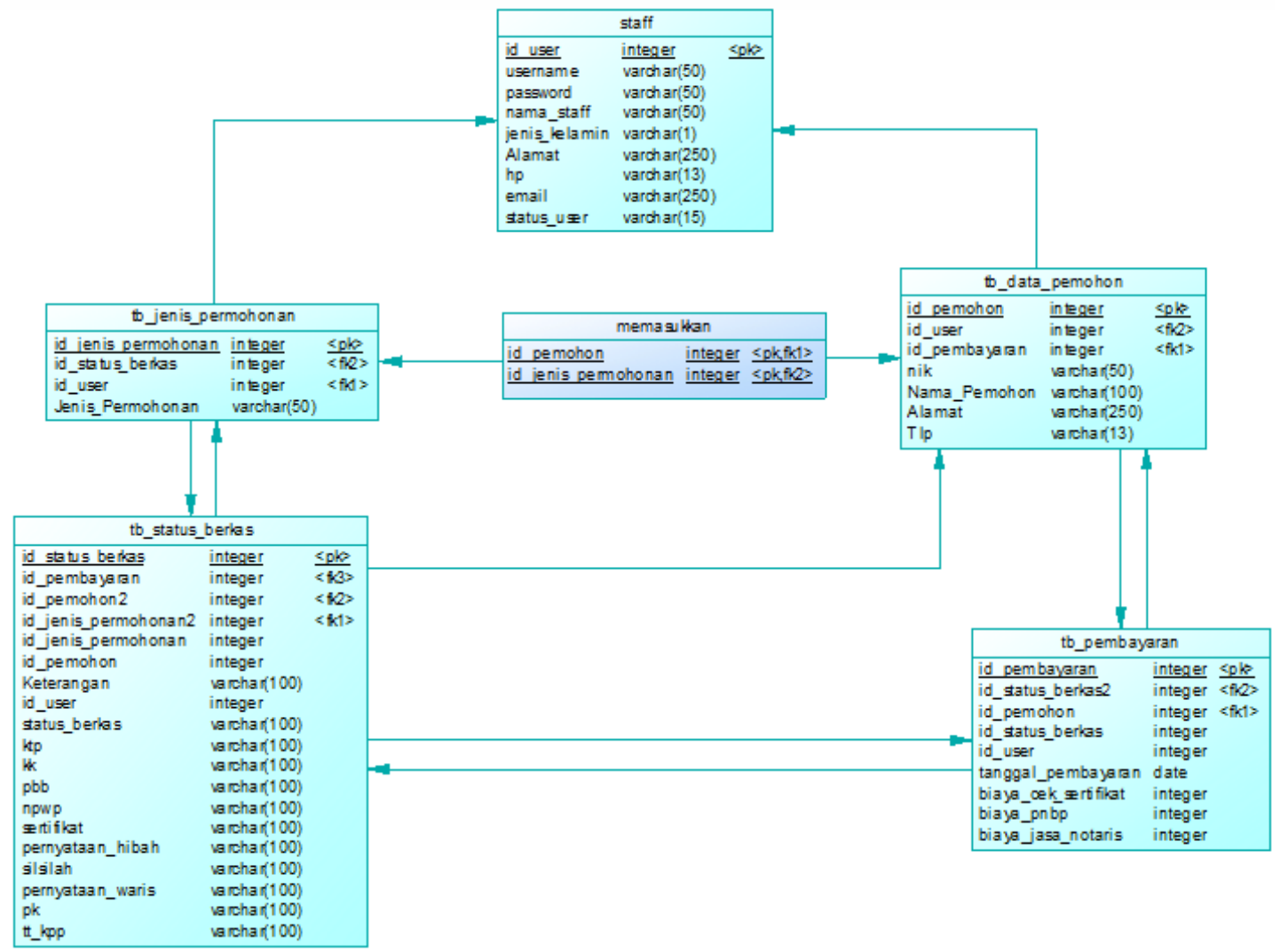

Gambar 3. Physical Data Model 


\subsection{Implementasi}

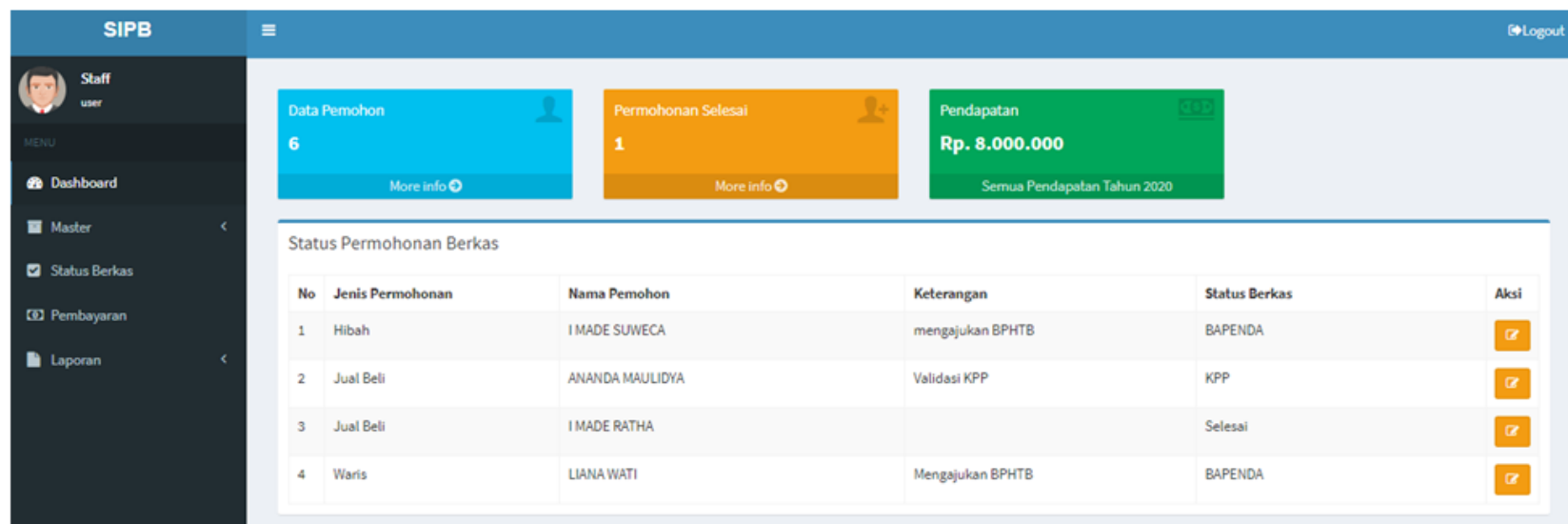

Gambar 4. Halaman dashboard

Pada gambar 4 merupakan tampilan halaman dashboard. Pada halaman dashboard ini pengguna dapat melihat berkas yang sedang diproses.

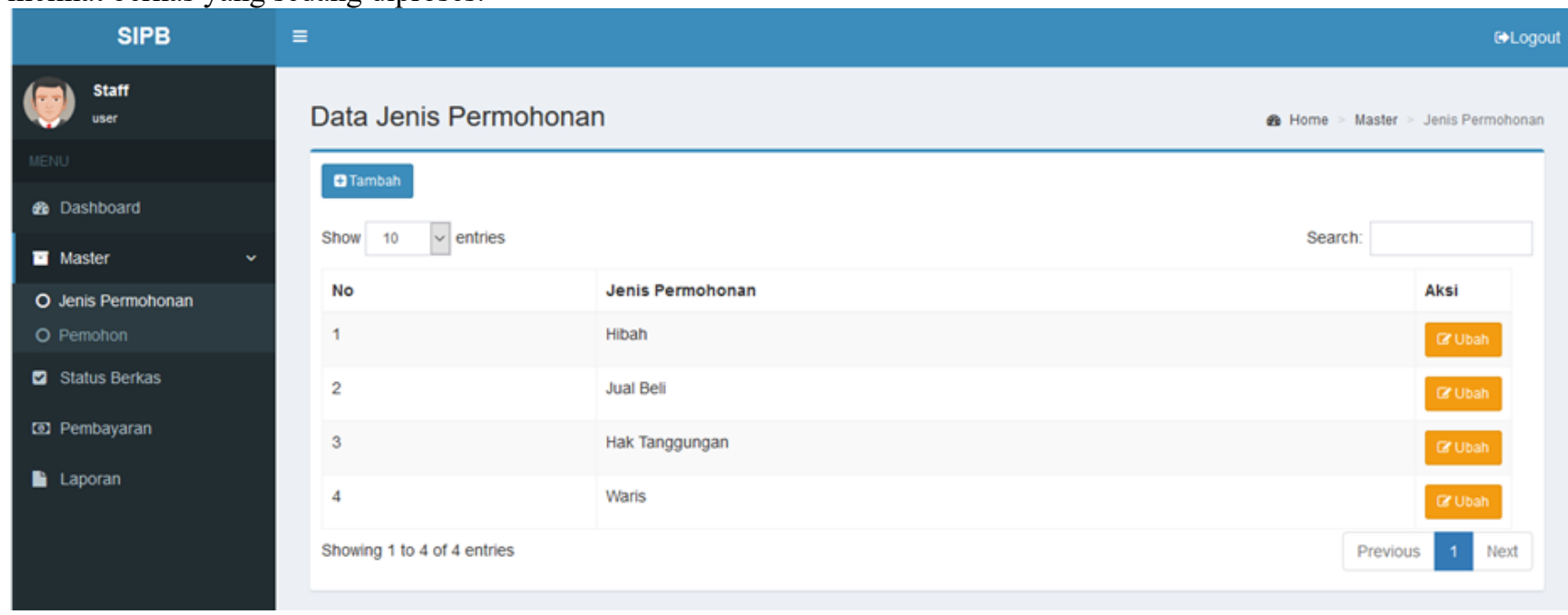

Gambar 5. Halaman jenis permohonan

Pada gambar 5 merupakan tampilan halaman jenis permohonan. Pada halaman ini staff melakukan proses tambah data jenis permohonan dan mengubah lalu menekan tombol simpan untuk menyimpan data.

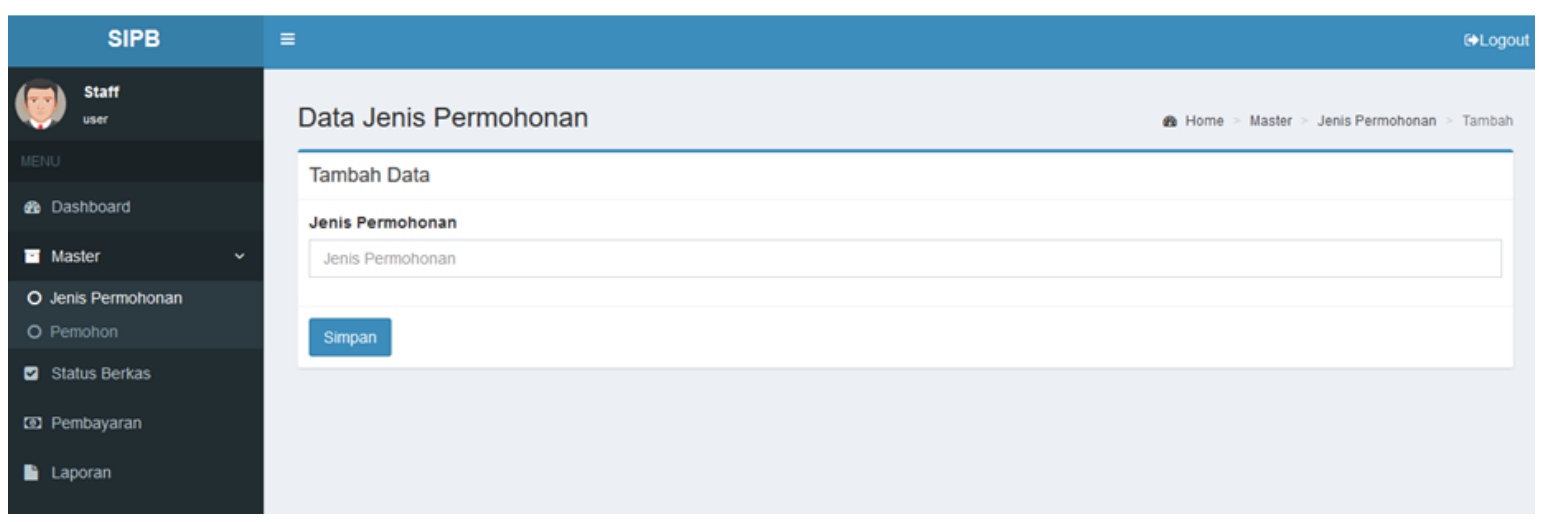

Gambar 6. Halaman Tambah Data pemohon 
Pada gambar 6 merupakan tampilan halaman tambah data pemohon. Pada halaman ini staff dapat melakukan proses tambah data pemohon baru dengan mengisi semua field yang tersedia, lalu menekan tombol simpan untuk menyimpan.

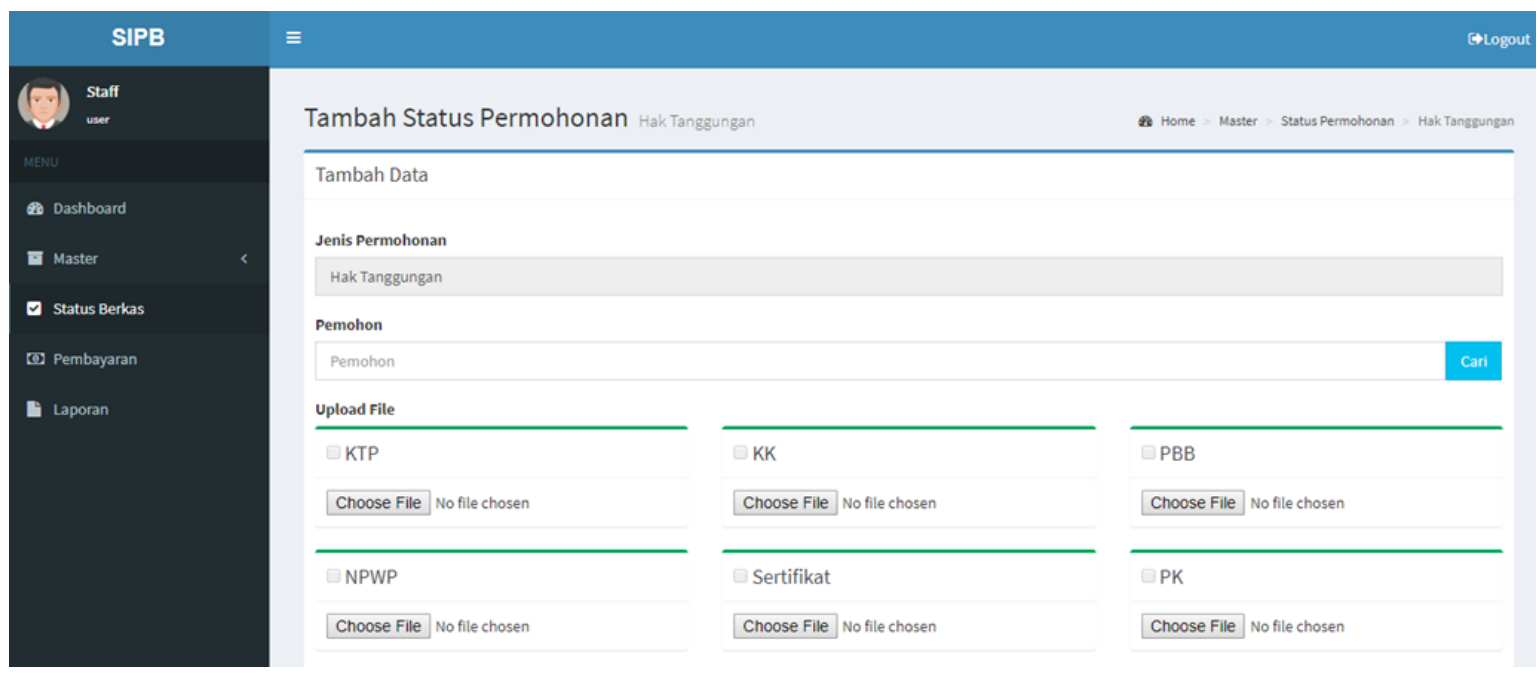

Gambar 7. Halaman Tambah status permohonan

Pada gambar 7 merupakan tampilan halaman tambah status permohonan. Pada halaman ini staff dapat melakukan proses tambah data status permohonan dengan mengisi semua field yang tersedia, lalu menekan tombol simpan untuk menyimpan data.

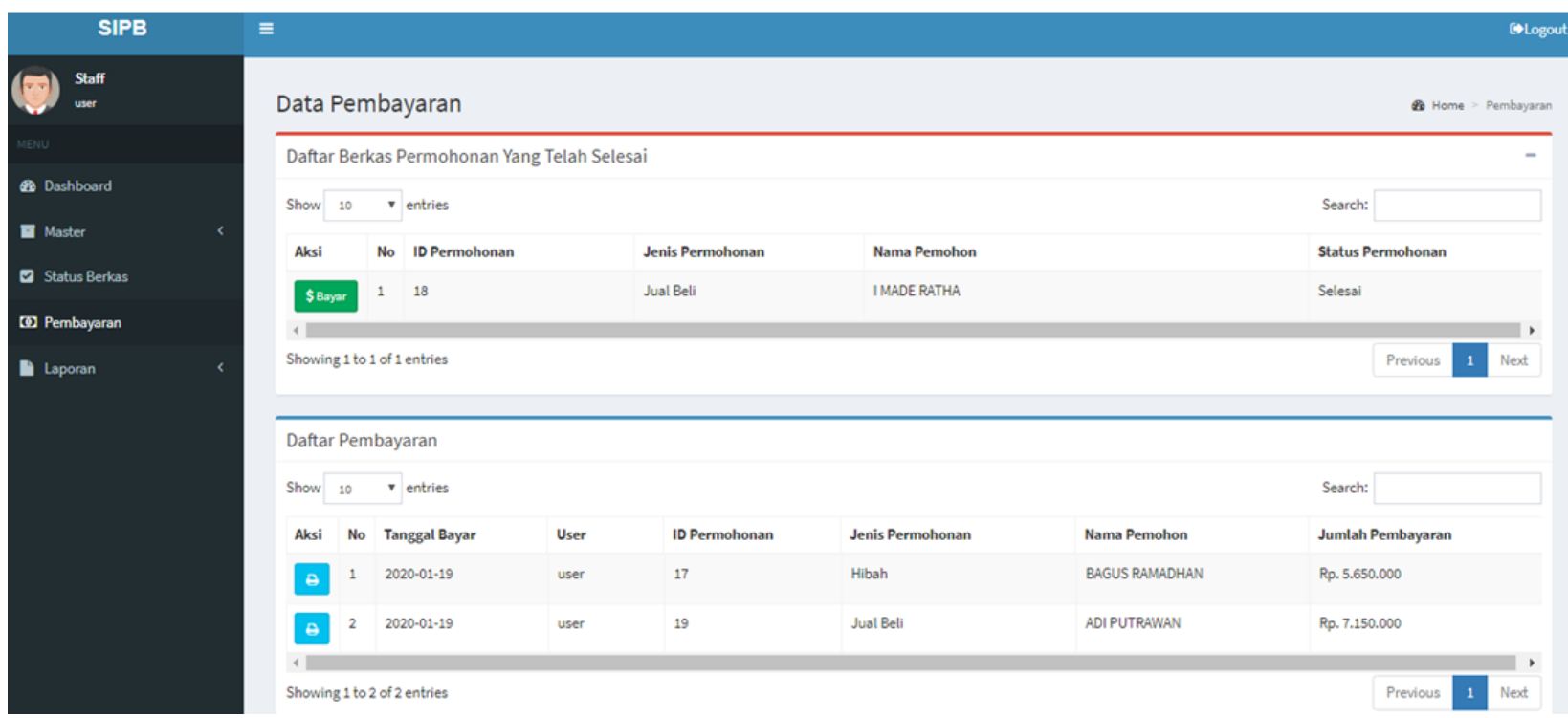

Gambar 8. Halaman Data Pembayaran

Pada gambar 8 merupakan tampilan halaman data pembayaran. Pada halaman ini pengguna dapat melakukan penginputan proses pembayaran, lalu menekan tombol simpan untuk menyimpan data. 


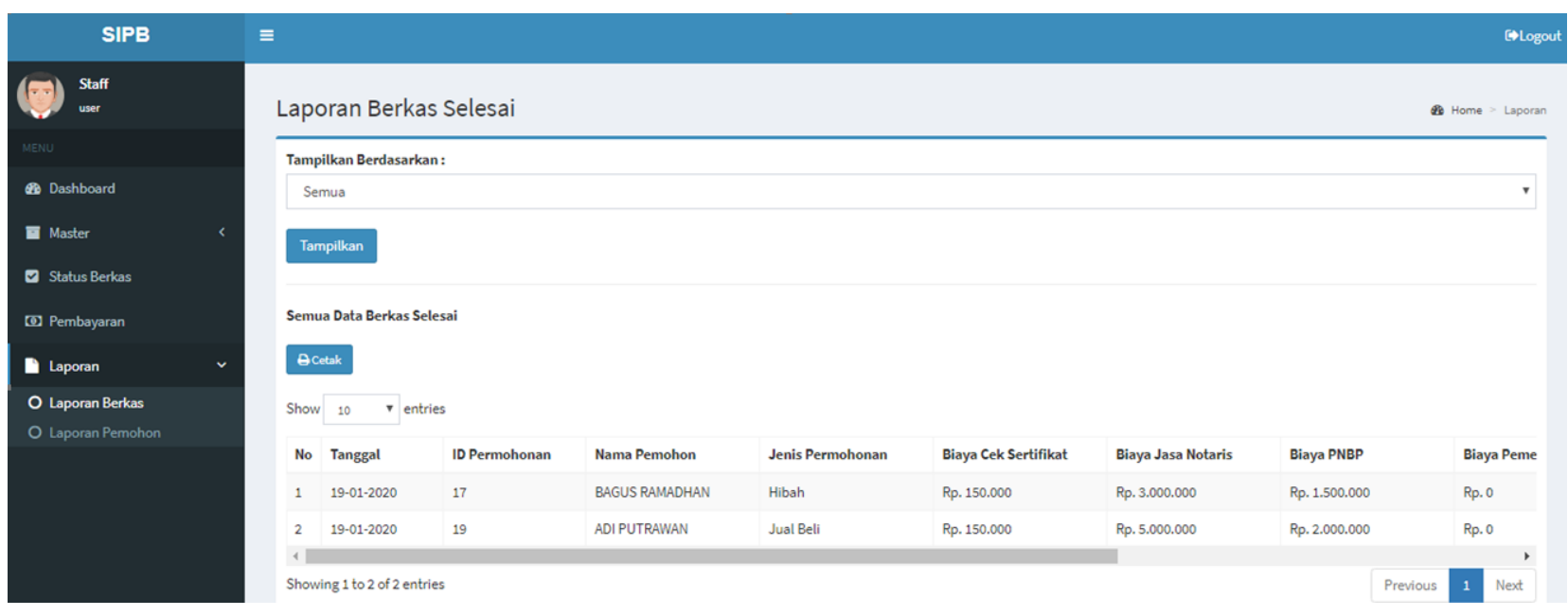

Gambar 9. Halaman Laporan Berkas Selesai.

Pada gambar 9 merupakan tampilan laporan berkas selesai yang mana diambil secara otomatis dari berkas yang telah dibayarkan oleh klien.

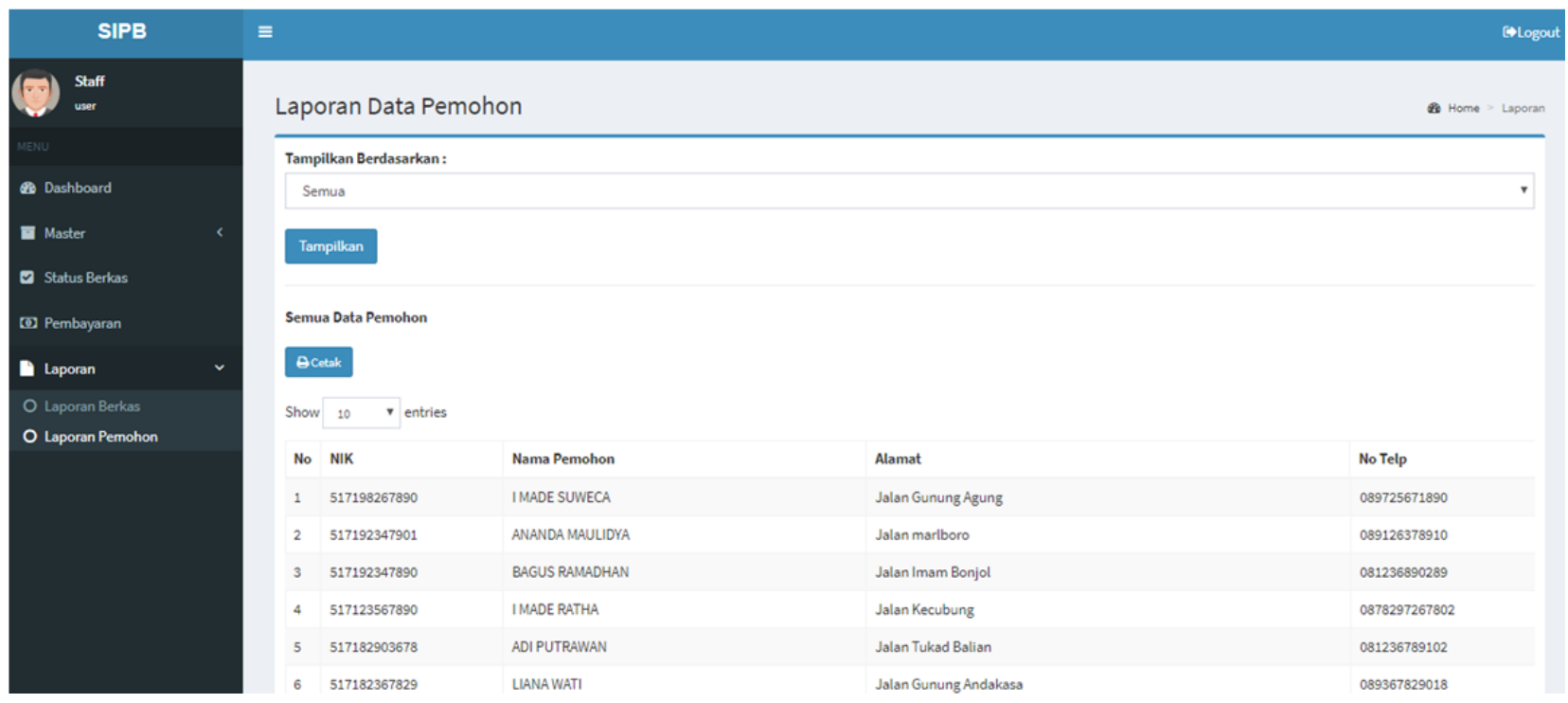

Gambar 10. Halaman Laporan Pemohon.

Pada gambar 10 merupakan tampilan laporan pemohon yang diambil secara otomatis diambil dari data pemohon.

\subsection{Pengujian}

Pengujian ini merupakan pengujian yang di lakukan untuk memastikan bahwa semua fungsional sistem yang dapat diakses berjalan sesuai dengan seharusnya. Berikut ini merupakan tabel pengujian halaman login yang akan di ujikan menggunakan metode black box. Tabel pengujian login dapat dilihat pada tabel 1.

Tabel 1. pengujian login .

\begin{tabular}{|c|l|l|l|}
\hline No. & \multicolumn{1}{|c|}{ Skenario } & \multicolumn{1}{|c|}{ Hasil Yang Diharapkan } & \multicolumn{1}{c|}{ Hasil Pengujian } \\
\hline \multirow{2}{*}{1.} & $\begin{array}{l}\text { Login dengan } \\
\text { username dan password } \\
\text { yang valid }\end{array}$ & $\begin{array}{l}\text { Sistem menampilkan pesan } \\
\text { login berhasil dan masuk ke } \\
\text { halaman dashboard. }\end{array}$ & $\begin{array}{l}\text { Valid (gambar pesan login } \\
\text { berhasil dan gambar } \\
\text { halaman dashboard). }\end{array}$ \\
\cline { 2 - 4 } & $\begin{array}{l}\text { Login dengan } \text { username } \\
\text { dan password yang tidak } \\
\text { valid }\end{array}$ & $\begin{array}{l}\text { Sistem menampilkan pesan } \\
\text { username atau password } \\
\text { salah. }\end{array}$ & $\begin{array}{l}\text { Valid (gambar pesan } \\
\text { username atau password } \\
\text { salah). }\end{array}$ \\
\hline
\end{tabular}




\begin{tabular}{|l|l|l|l|}
\hline No. & Skenario & Hasil Yang Diharapkan & Hasil Pengujian \\
\hline & & & \\
\hline
\end{tabular}

Tabel pengujian halaman pemohon terdapat 3 kondisi yang akan diujikan menggunakan metode black box testing yaitu menambah data pemohon, mengubah data pemohon dan mencari data pemohon. Tabel pengujian halaman pemohon dapat dilihat pada tabel 2 .

Tabel 2 pengujian halaman pemohon.

\begin{tabular}{|c|c|c|c|}
\hline No. & Skenario & Hasil Yang Diharapkan & Hasil Pengujian \\
\hline \multirow{6}{*}{2.} & $\begin{array}{l}\text { Menambah data } \\
\text { pemohon dengan } \\
\text { melengkapi seluruh } \\
\text { field }\end{array}$ & $\begin{array}{l}\text { Sistem akan } \\
\text { menyimpan data pemohon ke } \\
\text { database, dan menampilkan } \\
\text { data pemohon yang sudah } \\
\text { diinputkan pada tabel yang } \\
\text { tersedia. }\end{array}$ & $\begin{array}{l}\text { Valid (gambar pesan tambah } \\
\text { data pemohon berhasil } \\
\text { disimpan dan } \\
\text { menampilkannya pada } \\
\text { halaman pemohon) }\end{array}$ \\
\hline & $\begin{array}{l}\text { Menambah data } \\
\text { pemohon dengan } \\
\text { mengkosongkan } \\
\text { beberapa atau } \\
\text { salah satu field }\end{array}$ & $\begin{array}{l}\text { Sistem menampilkan } \\
\text { pesan field harus diisi dan } \\
\text { mengarahkan ke field yang } \\
\text { kosong tersebut. }\end{array}$ & $\begin{array}{l}\text { Valid (gambar tambah data } \\
\text { jaminan gagal dan } \\
\text { menampilkan pesan field } \\
\text { harus diisi serta mengarahkan } \\
\text { ke field yang kosong tersebut). }\end{array}$ \\
\hline & $\begin{array}{l}\text { Mengubah data } \\
\text { pemohon dengan } \\
\text { melengkapi seluruh } \\
\text { field }\end{array}$ & $\begin{array}{l}\text { Sistem akan mengubah data } \\
\text { pemohon yang sudah } \\
\text { diinputkan pada kolom tabel } \\
\text { yang tersedia dan } \\
\text { menyimpannya pada database }\end{array}$ & $\begin{array}{l}\text { Valid (gambar pesan ubah } \\
\text { data pemohon berhasil } \\
\text { disimpan dan } \\
\text { menampilkannya } \\
\text { pada halaman pemohon) }\end{array}$ \\
\hline & $\begin{array}{l}\text { Mengubah data } \\
\text { pemohon dengan } \\
\text { mengkosongkan salah } \\
\text { satu atau beberapa field }\end{array}$ & $\begin{array}{l}\text { Sistem menampilkan pesan } \\
\text { field harus diisi! dan } \\
\text { mengarahkan ke } \\
\text { field yang kosong } \\
\text { tersebut. }\end{array}$ & $\begin{array}{l}\text { Valid (gambar ubah data } \\
\text { pemohon gagal dan } \\
\text { menampilkan pesan field } \\
\text { harus diisi serta mengarahkan } \\
\text { ke field yang kosong tersebut). }\end{array}$ \\
\hline & $\begin{array}{l}\text { Mencari data } \\
\text { pemohon yang } \\
\text { tersedia }\end{array}$ & $\begin{array}{l}\text { Data pemohon } \\
\text { berhasil ditemukan } \\
\text { dan menampilkan } \\
\text { data yang dicari. }\end{array}$ & $\begin{array}{l}\text { Valid (gambar pencarian data } \\
\text { pemohon ditemukan dan } \\
\text { menampilkan data pada tabel). }\end{array}$ \\
\hline & $\begin{array}{l}\text { Mencari data } \\
\text { pemohon tidak } \\
\text { tersedia }\end{array}$ & $\begin{array}{l}\text { Tidak menampilkan hasil } \\
\text { pencarian data pemohon. }\end{array}$ & $\begin{array}{l}\text { Valid (gambar pencarian data } \\
\text { tidak ditemukan, dan } \\
\text { tidak ada data yang } \\
\text { ditampilkan pada tabel). }\end{array}$ \\
\hline
\end{tabular}

Berikut ini merupakan tabel pengujian halaman status permohonan terdapat 2 kondisi yang akan diujikan menggunakan metode black box testing yaitu menambah data status permohonan, dan mencari data status permohonan. Tabel pengujian halaman status permohonan dapat dilihat pada tabel 3 .

Tabel 3. pengujian halaman status berkas.

\begin{tabular}{|c|l|l|l|}
\hline No. & \multicolumn{1}{|c|}{ Skenario } & \multicolumn{1}{|c|}{ Hasil Yang Diharapkan } & \multicolumn{1}{c|}{ Hasil Pengujian } \\
\hline \multirow{3}{*}{3.} & $\begin{array}{l}\text { Menambahkan data status } \\
\text { permohonan dengan } \\
\text { melengkapi seluruh field }\end{array}$ & $\begin{array}{l}\text { Sistem akan } \\
\text { menyimpan data ke } \\
\text { database, dan menampilkan } \\
\text { data status permohonan } \\
\text { yang sudah diinputkan } \\
\text { pada tabel yang tersedia }\end{array}$ & $\begin{array}{l}\text { Valid (gambar pesan } \\
\text { tambah data status } \\
\text { permohonan } \\
\text { berhasil disimpan } \\
\text { dan menampilkannya pada } \\
\text { halaman status } \\
\text { permohonan) }\end{array}$ \\
\cline { 2 - 4 } & $\begin{array}{l}\text { Menambahkan data status } \\
\text { permohonan dengan } \\
\text { mengkosongkan beberapa } \\
\text { atau salah satu field }\end{array}$ & $\begin{array}{l}\text { Sistem menampilkan pesan } \\
\text { field } \text { harus diisi dan } \\
\text { mengarahkan ke field yang } \\
\text { kosong tersebut. }\end{array}$ & $\begin{array}{l}\text { Valid (gambar tambah data } \\
\text { gagal dan menampilkan } \\
\text { pesan field harus } \\
\text { diisi serta mengarahkan ke }\end{array}$ \\
\hline
\end{tabular}




\begin{tabular}{|c|c|c|c|}
\hline No. & Skenario & Hasil Yang Diharapkan & Hasil Pengujian \\
\hline & & & $\begin{array}{l}\text { field yang kosong } \\
\text { tersebut). }\end{array}$ \\
\hline & $\begin{array}{l}\text { Cari data } \\
\text { status permohonan } \\
\text { tersedia }\end{array}$ & $\begin{array}{l}\text { Data status permohonan } \\
\text { berhasil ditemukan } \\
\text { dan menampilkan data yang } \\
\text { dicari. }\end{array}$ & $\begin{array}{l}\text { Valid (gambar pencarian } \\
\text { data status berpermohonan } \\
\text { ditemukan dan } \\
\text { menampilkan data pada } \\
\text { tabel). }\end{array}$ \\
\hline & $\begin{array}{l}\text { Cari data status } \\
\text { permohonan tidak } \\
\text { tersedia }\end{array}$ & $\begin{array}{l}\text { Tidak menampilkan hasil } \\
\text { pencarian data pengajuan } \\
\text { status permohonan. }\end{array}$ & $\begin{array}{l}\text { Valid (gambar pencarian } \\
\text { data tidak ditemukan dan } \\
\text { tidak ada data yang } \\
\text { ditampilkan pada } \\
\text { tabel). }\end{array}$ \\
\hline
\end{tabular}

Berikut ini merupakan tabel pengujian halaman pembayaran terdapat 2 kondisi yang akan diujikan menggunakan metode black box testing yaitu mencetak bukti pembayaran dan mencari data pembayaran. Tabel pengujian halaman dapat dilihat pada tabel 4 .

Tabel 4. pengujian halaman pembayaran.

\begin{tabular}{|c|l|l|l|}
\hline No. & \multicolumn{1}{|c|}{ Skenario } & \multicolumn{1}{|c|}{ Hasil Yang Diharapkan } & \multicolumn{1}{c|}{ Hasil Pengujian } \\
\hline \multirow{2}{*}{4.} & $\begin{array}{l}\text { Mencetak bukti } \\
\text { pembayaran }\end{array}$ & $\begin{array}{l}\text { Menampilkan print } \\
\text { priview bukti transaksi } \\
\text { pembayaran yang akan } \\
\text { dicetak }\end{array}$ & $\begin{array}{l}\text { Valid (gambar print priview } \\
\text { bukti transaksi pembayaran) }\end{array}$ \\
\cline { 2 - 4 } & $\begin{array}{l}\text { Cari data } \\
\text { pembayaran tersedia }\end{array}$ & $\begin{array}{l}\text { Data transaksi } \\
\text { pembayaran berhasil } \\
\text { ditemukan dan menampilkan } \\
\text { data yang dicari. }\end{array}$ & $\begin{array}{l}\text { Valid (gambar pencarian } \\
\text { data pembayaran ditemukan } \\
\text { dan menampilkan data pada } \\
\text { tabel). }\end{array}$ \\
\cline { 2 - 4 } & $\begin{array}{l}\text { Cari data } \\
\text { pembayaran tidak } \\
\text { tersedia }\end{array}$ & $\begin{array}{l}\text { Tidak menampilkan hasil } \\
\text { pencarian data pembayaran. }\end{array}$ & $\begin{array}{l}\text { Valid (gambar pencarian } \\
\text { data pembayaran tidak } \\
\text { ditemukan, tidak ada data } \\
\text { yang ditampilkan pada } \\
\text { tabel). }\end{array}$ \\
\hline
\end{tabular}

Tabel 5. pengujian halaman laporan pemohon.

\begin{tabular}{|c|l|l|l|}
\hline No. & \multicolumn{1}{|c|}{ Skenario } & \multicolumn{1}{|c|}{ Hasil Yang Diharapkan } & \multicolumn{1}{c|}{ Hasil Pengujian } \\
\hline \multirow{2}{*}{5.} & $\begin{array}{l}\text { Melihat laporan } \\
\text { pemohon berdasarkan } \\
\text { periode yang tepat }\end{array}$ & $\begin{array}{l}\text { Menampilkan laporan } \\
\text { pemohon pada tabel sesuai } \\
\text { dengan periode yang } \\
\text { diminta. }\end{array}$ & $\begin{array}{l}\text { Valid (gambar menampilkan } \\
\text { data pada tabel sesuai } \\
\text { dengan periode yang } \\
\text { diminta) }\end{array}$ \\
\cline { 2 - 4 } & $\begin{array}{l}\text { Melihat laporan } \\
\text { pemohon berdasarkan } \\
\text { periode yang } \\
\text { tidak tersedia }\end{array}$ & $\begin{array}{l}\text { Tidak menampilkan hasil } \\
\text { pencarian data laporan } \\
\text { pemohon. }\end{array}$ & $\begin{array}{l}\text { Valid (gambar pencarian } \\
\text { data laporan pemohon tidak } \\
\text { ditemukan, tidak ada data } \\
\text { yang ditampilkan pada } \\
\text { tabel). }\end{array}$ \\
\hline
\end{tabular}

\section{Conclusion}

Berdasarkan hasil penelitian yang telah dilakukan dalam merancang dan membangun sistem informasi pengelolaan berkas pada Kantor Notaris/PPAT I Gusti Rai Daniel Ari Putra, SH., M.Kn. maka diambil kesimpulan sebagai berikut :

1. Analisa sistem informasi kantor Notaris/PPAT I Gusti Rai Daniel, SH., M.Kn dimulai dari proses pengumpulan data mengenai permasalahan yang muncul pada proses pengelolaan berkas telah berhasil dirancang dan dibangun dengan melalui proses identifikasi masalah, analisa kebutuhan, perancangan sistem, penulisan kode sistem, dan pengujian sistem. Perancangan sistem ini dilakukan menggunakan pemodelan Data Flow Diagram (DFD) untuk menggambarkan alur data dan pemodelan database menggunakan Conceptual Data Model (CDM) dan Physical Data Model (PDM). 
2. Berdasarkan pengujian sistem menggunakan metode black box testing, didapatkan hasil valid pada proses login yaitu dapat menampilkan halaman dashboard apabila berhasil masuk dan muncul pesan eror apabila terjadi kesalahan pada saat login.

3. Pada halaman pemohon terdapat tiga proses yang dapat dilakukan yaitu proses menambahkan pemohon, mengubah pemohon dan mencari pemohon. Apabila pada saat melakukan salah satu proses terdapat proses yang tidak sesuai maka akan muncul pesan peringatan.

4. Pada halaman status berkas terdapat tiga proses yang dapat dilakukan yaitu menambah berkas, mengubah data pada berkas dan mencari berkas. Jika pada saat berkas yang dicari tidak ditemukan maka akan muncul gambar pencarian data tidak ditemukan.

5. Pada halaman pembayaran terdapat dua proses yang dapat dilakukan yaitu mencetak dan mencari berkas pembayaran. Dan sebelum bukti pembayaran tercetak akan muncul hasil preview dari bukti pembayaran tersebut.

6. Pemohon dapat mencetak laporan permohonan sesuai dengan periode yang diinginkan.

\section{References}

[1] Undang-Undang Jabatan Notaris Nomor 2 Tahun 2014 Tentang Jabatan Notaris

[2] Peraturan Pemerintah Nomor 37 Tahun 1998 tentang Peraturan Jabatan Pejabat Pembuat Akta Tanah

[3] Peraturan Pemerintah Nomor 37 Tahun 1998 tentang Peraturan Jabatan Pejabat Pembuat Akta Tanah (PP Nomor 37 Tahun 1998)

[4] Hutahaean, Jeperson. 2015. Sistem Informasi Manajemen. Yogyakarta: Graha Ilmu

[5] Prasetyo, E., Komala, N., dkk. 2009. Rekayasa Perangkat Lunak. (A. Hendraputra, Ed.), 1 ed. Bandung: TELKOM POLYTECHNIC BANDUNG.

[6] Susanto, Azhar. 2013. Sistem Informasi Manajemen. Bandung: Lingga Jaya.

[7] Roiyansyah, Asmawi. 2014. Sistem Informasi Sirkulasi Berkas Di Kantor Notaris Dan Ppat Magdawati. 